\title{
Altering the ratio of dietary palmitic, stearic, and oleic acids in diets with or without whole cottonseed affects nutrient digestibility, energy partitioning, and production responses of dairy cows
}

\author{
J. de Souza, C. L. Preseault, and A. L. Lock ${ }^{1}$ \\ Department of Animal Science, Michigan State University, East Lansing 48824
}

\begin{abstract}
The objective of this study was to evaluate the effects of varying the ratio of dietary palmitic (C16:0), stearic (C18:0), and oleic (cis-9 C18:1) acids in basal diets containing soyhulls or whole cottonseed on nutrient digestibility, energy partitioning, and production response of lactating dairy cows. Twenty-four midlactation multiparous Holstein cows were used in a split-plot Latin square design. Cows were allocated to a main plot receiving either a basal diet with soyhulls $(\mathrm{SH}, \mathrm{n}=12)$ or a basal diet with whole cottonseed $(\mathrm{CS}, \mathrm{n}=12)$ that was fed throughout the experiment. Within each plot a $4 \times 4$ Latin square arrangement of treatments was used in 4 consecutive 21 -d periods. Treatments were (1) control (CON; no supplemental fat), (2) high C16:0 supplement [PA; fatty acid (FA) supplement blend provided $\sim 80 \%$ C16:0], (3) C16:0 and $\mathrm{C} 18: 0$ supplement $(\mathrm{PA}+\mathrm{SA}$; FA supplement blend provided $\sim 40 \% \mathrm{C} 16: 0+\sim 40 \% \mathrm{C} 18: 0$ ), and (4) C16:0 and cis-9 C18:1 supplement (PA+OA; FA supplement blend provided $\sim 45 \% \mathrm{C} 16: 0+\sim 35 \%$ cis-9 C18:1). Interactions between basal diets and FA treatments were observed for dry matter intake (DMI) and milk yield. Among the SH diets, PA and PA+SA increased DMI compared with $\mathrm{CON}$ and $\mathrm{PA}+\mathrm{OA}$ treatments, whereas in the CS diets PA+OA decreased DMI compared with $\mathrm{CON}$. The PA, PA+SA, and PA+OA treatments increased milk yield compared with CON in the $\mathrm{SH}$ diets. The CS diets increased milk fat yield compared with the $\mathrm{SH}$ diets due to the greater yield of de novo and preformed milk FA. The PA treatment increased milk fat yield compared with $\mathrm{CON}, \mathrm{PA}+\mathrm{SA}$, and $\mathrm{PA}+\mathrm{OA}$ due to the greater yield of mixed-source (16-carbon) milk FA. The PA treatment increased 3.5\% fat-corrected milk compared with CON and tended to increase it compared with $\mathrm{PA}+\mathrm{SA}$ and $\mathrm{PA}+\mathrm{OA}$. The $\mathrm{CS}$ diets increased body weight (BW) change compared with
\end{abstract}

Received July 7, 2017.

Accepted September 6, 2017.

${ }^{1}$ Corresponding author: allock@msu.edu the $\mathrm{SH}$ diets. Additionally, $\mathrm{PA}+\mathrm{OA}$ tended to increase BW change compared with CON and PA and increased it in comparison with $\mathrm{PA}+\mathrm{SA}$. The $\mathrm{PA}$ and $\mathrm{PA}+\mathrm{OA}$ treatments increased dry matter and neutral detergent fiber digestibility compared with $\mathrm{PA}+\mathrm{SA}$ and tended to increase them compared with $\mathrm{CON}$. The PA+SA treatment reduced 16-carbon, 18-carbon, and total FA digestibility compared with the other treatments. The CS diets increased energy partitioning toward body reserves compared with the $\mathrm{SH}$ diets. The PA treatment increased energy partitioning toward milk compared with $\mathrm{CON}$ and $\mathrm{PA}+\mathrm{OA}$ and tended to increase it compared with $\mathrm{PA}+\mathrm{SA}$. In contrast, $\mathrm{PA}+\mathrm{OA}$ increased energy partitioned to body reserves compared with PA and PA+SA and tended to increase it compared with CON. In conclusion, milk yield responses to different combinations of FA were affected by the addition of whole cottonseed in the diet. Among the combinations of C16:0, C18:0, and cis-9 C18:1 evaluated, fat supplements with more C16:0 increased energy output in milk, whereas fat supplements with more cis-9 C18:1 increased energy storage in BW. The combination of C16:0 and C18:0 reduced nutrient digestibility, which most likely explains the lower performance observed compared with other treatments.

Key words: dietary fatty acid, digestibility, nutrient partitioning, dairy cow

\section{INTRODUCTION}

Fat supplements are commonly added to dairy cow diets to increase dietary energy density and to support milk production (Rabiee et al., 2012). At the same time, recovery of body condition is important for improving reproductive performance while ensuring that it does not result in excessive body condition in later lactation. Therefore, understanding the effects of different fat sources on milk production and energy partitioning is crucial, and attention has lately been given to determining the effects of specific individual fatty acids (FA). Palmitic (C16:0), stearic (C18:0), and oleic (cis-9 C18:1) acids usually compose the majority of FA pres- 
ent in milk fat (Palmquist, 2006) and adipose tissue (Douglas et al., 2007) of dairy cows, and their proportions are affected by breed, lactation stage, seasonal variation, and dietary factors (Jensen, 2002). Although these FA have different functions in metabolism, they may also interact with each other by competition or complementary mechanisms. Therefore, determining an optimal dietary ratio among these FA may optimize their utilization.

Previous reports have indicated differences in intestinal digestibility among C16:0, C18:0, and cis-9 C18:1 (Glasser et al., 2008b; Boerman et al., 2015a). Recently, Boerman et al. (2017) fed increasing levels of a C18:0 -enriched supplement ( $93 \%$ C18:0) to dairy cows and observed no positive effect on production responses, which was likely associated with the pronounced decrease in total FA digestibility as FA intake increased. In contrast, Rico et al. (2017) fed increasing levels of a C16:0-enriched supplement ( $\sim 89 \%$ C16:0) to dairy cows and observed a slight decrease in total FA digestibility as FA intake increased but a positive effect on production response up to $1.5 \%$ of diet DM. Considering that the range of FA intake was similar across both studies (Boerman et al., 2017; Rico et al., 2017), the decrease in total FA digestibility was 3 times greater with increased intake and rumen outflow of C18:0 compared with C16:0. Regarding cis-9 C18:1, results have shown that this FA has greater digestibility than C16:0 and C18:0 (Boerman et al., 2015a). Also, Freeman (1969) examined the amphiphilic properties of polar lipid solutes and suggested that cis-9 C18:1 may have a positive effect on the micellar solubility of C18:0 that could increase 18-carbon FA digestibility.

Additionally, C16:0, C18:0, and cis-9 C18:1 are typically the most abundant FA found in commercial fat supplements commonly fed to dairy cows. The effects of these fat supplements on production, milk composition, and energy balance of dairy cows have been variable (Rabiee et al., 2012). These differences could be attributable to a series of factors related to the animal and the diet. One factor that may affect the response to fat supplementation is potential interactions with other dietary ingredients. Whole cottonseed is a by-product largely used in dairy rations because of its high content of energy, mainly in the form of oil, moderate level of $\mathrm{CP}$, and high effective fiber (Clark and Armentano, 1993; Moreira et al., 2004). Recently, we observed that milk fat yield responses to doses of C16:0 supplementation were affected by the inclusion of whole cottonseed (Rico et al., 2017). This increase in milk fat yield may be related to the greater amount of long-chain FA in whole cottonseed and potentially greater incorporation of preformed FA into milk fat (Harrison et al., 1995; Rico et al., 2017). Because milk lipid synthesis in the mammary gland is dependent on the simultaneous supply of short- or medium-chain FA and long-chain FA (Glasser et al., 2008a), this may suggest that milk fat responses to fat supplements that also provide longchain FA may be affected by the addition of whole cottonseed to diets. Also, if the amount of preformed FA surpasses mammary gland capacity, these might be redirected to other tissues (i.e., adipose tissue) altering energy partitioning. Therefore, the objective of our study was to evaluate the effects of varying the ratio of dietary C16:0, C18:0, and cis-9 C18:1 in basal diets with the inclusion of soyhulls or whole cottonseed on nutrient digestibility, energy partitioning, and production responses of lactating dairy cows. We hypothesized that reducing the amount of C16:0 in supplemental fat would reduce milk energy output due to differences in milk fat yield response and that the magnitude of the response to supplemental fat would be affected by the addition of whole cottonseed to diets.

\section{MATERIALS AND METHODS}

\section{Design and Treatments}

Experimental procedures were approved by the Institutional Animal Care and Use Committee at Michigan State University, East Lansing. Twenty-four mid-lactation, multiparous Holstein cows from the Michigan State University Dairy Field Laboratory, averaging $($ mean $\pm \mathrm{SD}) 134 \pm 34 \mathrm{DIM}$ and $690 \pm 75 \mathrm{~kg}$ of BW, were used in a split-plot Latin square design. All animals received a common diet with no fat supplementation during a 14-d preliminary period to obtain baseline values. This trial was designed to test the interaction between feeding a basal diet with soyhulls or whole cottonseed and fat supplements varying in the ratios of C16:0, C18:0, and cis-9 C18:1. Cows were assigned to a main plot, with 12 cows receiving a basal diet containing whole cottonseed (CS) and 12 cows receiving a basal diet containing soyhulls $(\mathbf{S H})$ throughout the trial. Whole cottonseed replaced soyhulls in the basal $\operatorname{diet}(8.6 \%$ of diet $\mathrm{DM})$, and all the other ingredients were fed at the same concentration. At the beginning of the trial, neither milk yield $(50.9 \mathrm{~kg} / \mathrm{d})$ nor $3.5 \% \mathrm{FCM}$ $(52.9 \mathrm{~kg} / \mathrm{d})$ differed between the $\mathrm{SH}$ and CS groups $(P=0.95$ and 0.94 , respectively). Within these basal diet groups, a Latin square design was used to apply FA treatments so that each animal received each of the 4 FA treatments but only 1 basal diet. This design provides less statistical power to test the main plot factor (basal diet: SH vs. CS) but gives more power to test the split-plot factors (FA treatments and interaction between basal diet and FA treatments; Kutner et al., 2005; Rico et al., 2017). 
Table 1. Composition of fatty acid (FA) supplements used to make the FA blends fed during the treatment periods $^{1}$

\begin{tabular}{|c|c|c|c|}
\hline \multirow[b]{2}{*}{ Item } & \multicolumn{3}{|c|}{ Fat supplement ${ }^{2}$} \\
\hline & $\begin{array}{l}\text { Bergafat } \\
\text { F-100 }\end{array}$ & $\begin{array}{c}\text { Energy } \\
\text { Booster } 100\end{array}$ & Megalac \\
\hline \multicolumn{4}{|l|}{ FA profile, $\mathrm{g} / 100 \mathrm{~g}$ of $\mathrm{FA}$} \\
\hline C14:0 & 0.40 & 2.4 & 0.84 \\
\hline $\mathrm{C} 16: 0$ & 88.7 & 36.3 & 46.1 \\
\hline C18:0 & 0.31 & 47.0 & 4.1 \\
\hline cis-9 C18:1 & 7.9 & 6.2 & 38.8 \\
\hline cis-9,cis-12 C18:2 & 2.0 & 0.75 & 8.5 \\
\hline cis-9,cis-12,cis-15 C18:3 & 0.03 & 0.03 & 0.24 \\
\hline Mean particle size, $\mu \mathrm{m}$ & 756 & 546 & 838 \\
\hline Melting point, ${ }^{\circ} \mathrm{C}$ & 60.4 & 57.2 & - \\
\hline Iodine value & 12.9 & 13.2 & - \\
\hline Free FA, \% & 98.7 & 88.6 & 0.02 \\
\hline Gross energy, Mcal/kg & 9.3 & 9.3 & 8.0 \\
\hline
\end{tabular}

Within each plot, a $4 \times 4$ balanced Latin square arrangement of treatments was used in 4 consecutive $21-\mathrm{d}$ periods. The 4 treatments were a control diet (no supplemental fat) and 3 blends of 3 commercially available FA supplements that differed in FA profile (Table 1). The FA supplements used were Bergafat F-100 (Berg + Schmidt America LLC, Libertyville, IL), Energy Booster 100 (Milk Specialties Global, Eden Prairie, MN), and Megalac (Church and Dwight Co. Inc., Princeton, NJ) that were blended to achieve different ratios of C16:0, C18:0, and cis-9 C18:1 in the FA supplement blends (Table 2). The FA treatments were control $(\mathbf{C O N}$; no supplemental fat), (2) C16:0 supplement (PA; 80\% of C16:0), (3) C16:0 and C18:0 supplement (PA+SA; $\sim 40 \%$ of $\mathrm{C} 16: 0+\sim 40 \%$ of $\mathrm{C} 18: 0$ ), and (4) C16:0 and cis-9 C18:1 supplement (PA+OA; $\sim 45 \%$ of $\mathrm{C} 16: 0+$ $\sim 35 \%$ of cis-9 C18:1). The FA supplement blends provided $1.5 \%$ of FA ( $\%$ diet DM), and diets were balanced for Ca concentration (Table 3 ).

Dry matter concentration of forages was determined twice weekly, and diets were adjusted when necessary. Throughout the experiment cows were housed in individual tiestalls. Access to feed was blocked daily from 0830 to $1000 \mathrm{~h}$ to allow for the collection of orts and offering feed. Cows were fed $115 \%$ of expected daily intake, and feed intake was recorded. Water was available ad libitum in each stall, and stalls were bedded with sawdust and cleaned twice per day.

Table 2. Proportion of each fatty acid (FA) supplement for treatment blends and FA profile of FA blends ${ }^{1}$

\begin{tabular}{lccc}
\hline & \multicolumn{3}{c}{ FA treatment $^{2}$} \\
\cline { 2 - 4 } Item & PA & PA+SA & PA+OA \\
\hline FA supplement in treatment blends, ${ }^{3} \%$ & 84.0 & 5.0 & 4.0 \\
Bergafat F-100 & 11.5 & 84.0 & 11.0 \\
Energy Booster 100 & 4.5 & 11.0 & 85.0 \\
Megalac & & & \\
FA profile of each FA blend, g/100 g of FA & 0.67 & 2.14 & 1.00 \\
C14:0 & 80.3 & 40.0 & 46.3 \\
C16:0 & 6.31 & 40.4 & 8.74 \\
C18:0 & 9.02 & 9.50 & 34.0 \\
cis-9 C18:1 & 2.10 & 1.58 & 7.59 \\
cis-9, cis-12 C18:2 & 0.04 & 0.05 & 0.21 \\
cis-9, cis-12,cis-15 C18:3 & & \\
\hline
\end{tabular}

${ }^{1}$ Average $(\mathrm{n}=4)$ based on samples taken during the last $5 \mathrm{~d}$ of the experimental period.

${ }^{2} \mathrm{PA}=1.5 \%$ of $\mathrm{FA}$ supplement blend to provide approximately $80 \%$ of $\mathrm{C} 16: 0$; $\mathrm{PA}+\mathrm{SA}=1.5 \%$ of $\mathrm{FA}$ supplement blend to provide approximately $40 \%$ of $\mathrm{C} 16: 0+40 \%$ of $\mathrm{C} 18: 0 ; \mathrm{PA}+\mathrm{OA}=1.5 \%$ of $\mathrm{FA}$ supplement blend to provide approximately $45 \%$ of $\mathrm{C} 16: 0+35 \%$ of $\mathrm{C} 18: 1$ cis-9.

${ }^{3}$ Bergafat F-100 (Berg + Schmidt America LLC, Libertyville, IL), Energy Booster 100 (Milk Specialties Global, Eden Prairie, MN), and Megalac (Church and Dwight Co. Inc., Princeton, NJ). 
Table 3. Ingredient and nutrient composition of treatment $\operatorname{diets}^{1}$

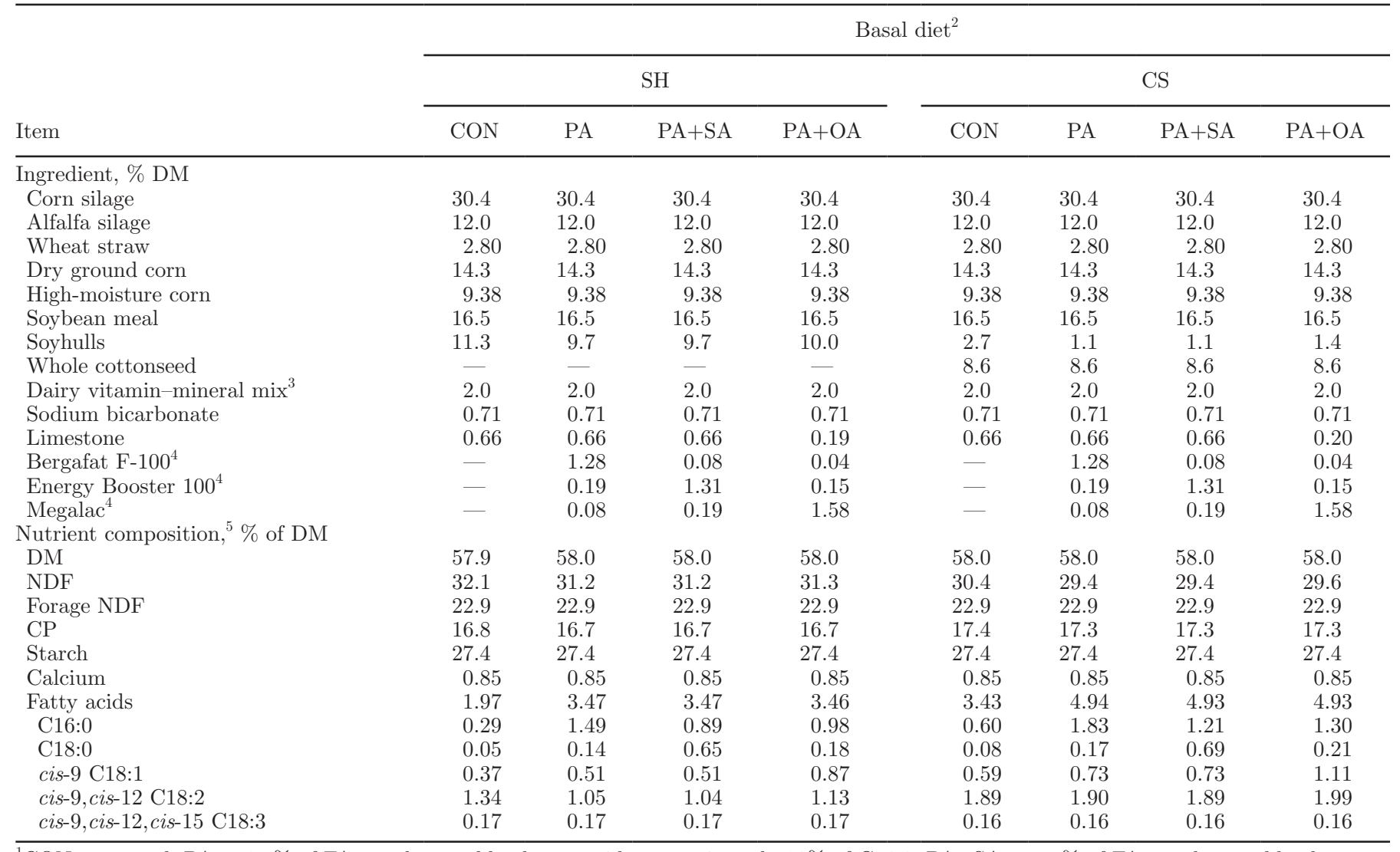

${ }^{1} \mathrm{CON}=$ control; $\mathrm{PA}=1.5 \%$ of $\mathrm{FA}$ supplement blend to provide approximately $80 \%$ of $\mathrm{C} 16: 0 ; \mathrm{PA}+\mathrm{SA}=1.5 \%$ of $\mathrm{FA}$ supplement blend to provide approximately $40 \%$ of $\mathrm{C} 16: 0+40 \%$ of $\mathrm{C} 18: 0 ; \mathrm{PA}+\mathrm{OA}=1.5 \%$ of FA supplement blend to provide approximately $45 \%$ of $\mathrm{C} 16: 0+35 \%$ of C18:1 cis-9.

${ }^{2}$ Basal diet includes diets with soyhulls (SH) and diets with whole cottonseed (CS).

${ }^{3}$ Vitamin and mineral mix contained $34.1 \%$ dry ground shelled corn, $25.6 \%$ white salt, $21.8 \%$ calcium carbonate, $9.1 \%$ Biofos (The Mosaic Co., Plymouth, MN), $3.9 \%$ magnesium oxide, $2 \%$ soybean oil, and $<1 \%$ of each of the following: manganese sulfate, zinc sulfate, ferrous sulfate, copper sulfate, iodine, cobalt carbonate, vitamin E, vitamin A, vitamin D, and selenium.

${ }^{4}$ Bergafat F-100 (Berg + Schmidt America LLC, Libertyville, IL), Energy Booster 100 (Milk Specialties Global, Eden Prairie, MN), and Megalac (Church and Dwight Co. Inc., Princeton, NJ).

${ }^{5}$ Expressed as a percentage of as fed.

\section{Data and Sample Collection}

Samples were collected during the last $5 \mathrm{~d}$ of each treatment period (d 17-21). Samples $(0.5 \mathrm{~kg}$ ) of all diet ingredients and orts (12.5\%) from each cow were collected daily and composited by period for analysis. Milk yield was recorded, and 2 milk samples were collected at each milking. One aliquot was collected in a sealed tube with preservative (bronopol tablet; D\&F Control Systems, San Ramon, CA) and stored at $4^{\circ} \mathrm{C}$ for milk component analysis. The second aliquot was stored without preservative at $-20^{\circ} \mathrm{C}$ until analysis for FA composition. Fecal $(\sim 400 \mathrm{~g})$ and blood $(\sim 15 \mathrm{~mL})$ samples were collected every $15 \mathrm{~h}$ for the last $5 \mathrm{~d}$ of each period, totaling 8 samples/cow per period. The 15-h interval over $5 \mathrm{~d}$ simulates sampling every $3 \mathrm{~h}$ over a 24 -h period. Feces were stored in a sealed plastic cup at $-20^{\circ} \mathrm{C}$. Blood was stored on ice until centrifugation at $2,000 \times g$ for $15 \mathrm{~min}$ at $4^{\circ} \mathrm{C}$ (within $30 \mathrm{~min}$ of sample collection). Plasma was transferred into microcentrifuge tubes and stored at $-20^{\circ} \mathrm{C}$ until composited by cow period.

Body weight measurements were taken 3 times per week following the morning milking, and BW change was calculated according to Boerman et al. (2015b). On the last day of the preliminary period and last day of each treatment period, 3 trained investigators determined BCS on a 5-point scale in 0.25-point increments (Wildman et al., 1982).

\section{Sample Analysis}

Diet ingredients, orts, and fecal samples were dried at $55^{\circ} \mathrm{C}$ in a forced-air oven for $72 \mathrm{~h}$ for DM determina- 
tion. Dried samples were ground with a Wiley mill (1mm screen; Arthur H. Thomas, Philadelphia, PA). Feed ingredients, orts, and feces were analyzed for NDF, CP, and starch concentration as described by Boerman et al. (2015b). The FA concentrations in feed ingredients, orts, and feces were determined as described by Piantoni et al. (2013). Indigestible NDF was determined after $240 \mathrm{~h}$ of in vitro fermentation (Goering and Van Soest, 1970) using rumen fluid from a nonlactating mature cow fed dry hay. The 3 commercial fat supplements used in the treatment blends were analyzed for particle size (method 965.22; AOAC, 1990), melting point (method Cc 1-25; AOCS, 2013), iodine value (method Cd 1d-92; AOCS, 2013), percentage of free FA (method Ca 5a-40; AOCS, 2013), and gross energy using bomb calorimeter by Eurofins Global Inc. (Des Moines, IA).

Milk samples were analyzed for fat, true protein, and lactose concentrations by mid-infrared spectroscopy (method 972.160, AOAC, 1990; Universal Lab Services, Lansing, MI). Yields of 3.5\% FCM, milk energy, and milk components were calculated using milk yield and component concentrations from each milking, summed for a daily total, and averaged for each collection period. Milk samples used for analysis of FA composition were composited based on milk fat yield (d 17-21 of each period). Milk lipids were extracted, and FA methyl esters were prepared and quantified using GLC according to Lock et al. (2013). Fatty acid composition covering approximately $70 \mathrm{FA}$ in the range $\mathrm{C} 4: 0$ to $\mathrm{C} 24: 0$ was determined by a GC-2010 Plus gas chromatograph (Shimadzu, Kyoto, Japan) with a split injector (1:100 split ratio) and a flame-ionization detector using a CP-Sil 88 wall-coated open tubular fused-silica column $(100 \mathrm{~m} \times 0.25 \mathrm{~mm}$ i.d. $\times 0.2-\mu \mathrm{m}$ film thickness; Varian Inc., Lake Forest, CA). Yield of individual FA (g/d) in milk fat was calculated by using milk fat yield and FA concentration to determine yield on a mass basis using the molecular weight of each FA while correcting for glycerol content and other milk lipid classes (Piantoni et al., 2013). The FA yield response to additional FA intake (FAYR) was calculated as FAYR $(\%)=[(\mathrm{FA}$ yield for fat-supplemented diet - FA yield for CON)/ (FA intake for fat-supplemented diet - FA intake for $\mathrm{CON})] \times 100$.

We determined energy partitioning using the procedures described by Boerman et al. (2015b). Data were used to calculate milk energy output and body tissue gain throughout each treatment period. Milk energy output (Mcal/d) was calculated according to NRC (2001) as

$$
\begin{aligned}
& \text { milk energy output }(\mathrm{Mcal} / \mathrm{d})=[9.29 \times \text { fat }(\mathrm{kg}) \\
& +5.63 \times \text { true protein }(\mathrm{kg})+3.95 \times \text { lactose }(\mathrm{kg})]
\end{aligned}
$$

where each component was based on the average output of a cow during the 5-d sampling period. Mean daily BW change $(\mathrm{kg} / \mathrm{d})$ was calculated for each cow within period by linear regression after 2 iterations of removing outliers. Energy partitioned to body tissue gain (Mcal/d) was estimated according to NRC (2001) as

$$
\begin{gathered}
\text { body tissue gain }(\mathrm{Mcal} / \mathrm{d})= \\
{[(2.88+1.036 \times \mathrm{BCS}) \times \Delta \mathrm{BW}],}
\end{gathered}
$$

where BCS was the average BCS for each cow during a 21-d period.

Apparent $\mathrm{NE}_{\mathrm{L}}$ concentration of the diet was calculated from the digestibility results as described by Harvatine and Allen (2006). Energy intake was calculated for individual cows for each treatment from apparent $\mathrm{NE}_{\mathrm{L}}$ of diet $\times$ DMI. Energy for maintenance (Mcal/d) was the difference between the energy intake and energy allocated to milk and BW.

All plasma samples were analyzed in duplicate with a coefficient of variation of $<5 \%$ between duplicates. Insulin was measured with a bovine insulin ELISA using a solid phase 2-site enzyme immunoassay (Mercodia, Uppsala, Sweden).

\section{Statistical Analysis}

All data were analyzed using the mixed model procedure of SAS (version 9.4; SAS Institute, Cary, NC) according to the following model:

$$
\mathrm{Y}_{\mathrm{ijkl}}=\mu+\mathrm{F}_{\mathrm{i}}+\mathrm{C}_{\mathrm{j}}\left(\mathrm{F}_{\mathrm{i}}\right)+\mathrm{P}_{\mathrm{k}}+\mathrm{T}_{1}+\mathrm{F}_{\mathrm{i}} \times \mathrm{T}_{1}+\mathrm{e}_{\mathrm{ijk} \mathrm{k}},
$$

where $Y_{\mathrm{ijkl}}=$ dependent variable, $\mu=$ overall mean, $F_{\mathrm{i}}$ = fixed effect of basal diet group $(i=2), C_{j}\left(F_{i}\right)=$ random effect of cow within the main plot $(\mathrm{j}=1-12), \mathrm{P}_{\mathrm{k}}=$ fixed effect of period $(\mathrm{k}=1-4), \mathrm{T}_{1}=$ fixed effect of $\mathrm{FA}$ treatment $(1=1-4)$, and $\mathrm{e}_{\mathrm{ijkl}}=$ residual error. Normality of the residuals was checked with normal probability and box plots and homogeneity of variances with plots of residuals versus predicted values. Main effects were declared significant at $P \leq 0.05$, and tendencies were declared at $0.05<P \leq 0.10$. Interactions were declared significant at $P \leq 0.10$, and tendencies were declared at $0.10<P \leq 0.15$. Interactions between treatment and period and between basal diet group and period were evaluated but removed from the statistical model when not significant $(P>0.20)$. Treatment means were compared using the protected least significant difference test for the main effect of FA treatment and the interaction between basal diet and FA treatments. All data were expressed as least squares means and standard error of the means. 


\section{RESULTS}

\section{Nutrient Intake and Total-Tract Digestibility}

We observed an interaction between basal diet and FA treatments for DMI (Table $4 ; P<0.10$ ). For the SH diets, $\mathrm{PA}$ and $\mathrm{PA}+\mathrm{SA}$ increased DMI compared with $\mathrm{CON}$ and $\mathrm{PA}+\mathrm{OA}$ treatments $(P<0.05)$, whereas in the $\mathrm{CS}$ diets, $\mathrm{PA}+\mathrm{OA}$ decreased $\mathrm{DMI}$ compared with CON (Figure 1A; $P<0.05$ ). No interaction between basal diet and FA treatments was observed for nutrient intake (all $P>0.15$ ). Also, we observed an interaction between basal diet and FA treatments for 16-carbon FA digestibility $(P<0.10)$ due to PA decreasing 16 -carbon FA digestibility compared with $\mathrm{CON}$ in the $\mathrm{SH}$ diets $(P$ $<0.05$ ) but not in the CS diets (Figure 1B; $P>0.15$ ).

No differences in DMI between SH and CS diets were observed (Table $4 ; P<0.10$ ). In contrast, CS diets decreased NDF intake $(P<0.05)$ and increased intakes of 16-carbon FA $(P<0.05), 18$-carbon FA $(P<0.05)$, and total FA $(P<0.05)$ compared with SH diets. Compared with SH diets, CS diets decreased digestibilities of NDF $(P<0.05), 18$-carbon FA $(P<0.05)$, and total FA $(P<0.05)$ and tended to decrease 16 -carbon FA digestibility $(P<0.10)$.

The $\mathrm{PA}+\mathrm{OA}$ treatment decreased DMI compared with PA $(P<0.05)$ and PA+SA $(P<0.05)$ and tended to decrease it compared with CON $(P<0.10)$. All FA treatments increased total FA intake compared with CON $(P<0.05)$. Both $\mathrm{PA}$ and $\mathrm{PA}+\mathrm{OA}$ increased
DM digestibility compared with $\mathrm{PA}+\mathrm{SA}(P<0.05)$ and tended to increase it compared with $\mathrm{CON}(P<$ $0.10)$. Also, PA and PA+OA increased NDF digestibility compared with other treatments $(P<0.05)$. The $\mathrm{PA}+\mathrm{SA}$ treatment decreased 16-carbon, 18-carbon, and total FA digestibility compared with other treatments $(P<0.05)$. The PA treatment decreased 16-carbon FA digestibility compared with $\mathrm{CON}(P<0.05)$ and $\mathrm{PA}+\mathrm{OA}(P<0.05)$. No differences between PA and CON were observed for digestibilities of 18-carbon FA and total FA $(P>0.10)$. The PA+OA treatment increased 16-carbon and total FA digestibilities compared with $\mathrm{PA}$ and $\mathrm{PA}+\mathrm{SA}(P<0.05)$.

We estimated the apparent digestibility of the supplemental FA blends by using a Lucas test (Figure 2). The slopes (i.e., digestibility of the supplemental FA blends) in SH diets were 0.64, 0.55, and 0.75 for PA, $\mathrm{PA}+\mathrm{SA}$, and $\mathrm{PA}+\mathrm{OA}$, respectively, and in $\mathrm{CS}$ diets were $0.70,0.56$, and 0.81 for $\mathrm{PA}, \mathrm{PA}+\mathrm{SA}$, and $\mathrm{PA}+\mathrm{OA}$, respectively.

\section{Production Responses}

The interaction between basal diet and FA treatments was not significant for most production variables (Table 5). We observed an interaction between basal diet and FA treatments for milk yield due to FA treatments increasing milk yield in the $\mathrm{SH}$ diets but not in the CS diets $(P<0.10$; Figure $3 \mathrm{~A})$. We also observed

Table 4. Nutrient intake and nutrient digestibility for cows fed fatty acid (FA) treatment diets $(\mathrm{n}=24)$

\begin{tabular}{|c|c|c|c|c|c|c|c|c|c|c|c|}
\hline \multirow[b]{2}{*}{ Variable } & \multicolumn{4}{|c|}{ FA treatment ${ }^{1}$} & \multicolumn{3}{|c|}{ Basal diet ${ }^{2}$} & \multirow[b]{2}{*}{ SEM } & \multicolumn{3}{|c|}{$P$-value ${ }^{3}$} \\
\hline & $\mathrm{CON}$ & PA & $\mathrm{PA}+\mathrm{SA}$ & $\mathrm{PA}+\mathrm{OA}$ & SEM & $\mathrm{SH}$ & $\mathrm{CS}$ & & $\begin{array}{c}\text { Basal } \\
\text { diet }\end{array}$ & FA & $\begin{array}{c}\text { Basal diet } \\
\times \text { FA }\end{array}$ \\
\hline \multicolumn{12}{|l|}{ Intake, $\mathrm{kg} / \mathrm{d}$} \\
\hline $\mathrm{DM}$ & $29.6^{\mathrm{ab}}$ & $30.0^{\mathrm{a}}$ & $29.8^{\mathrm{a}}$ & $28.9^{\mathrm{b}}$ & 0.39 & 29.6 & 29.5 & 0.52 & 0.81 & 0.06 & 0.05 \\
\hline NDF & $9.21^{\mathrm{a}}$ & $9.10^{\mathrm{a}}$ & $9.01^{\mathrm{a}}$ & $8.82^{\mathrm{b}}$ & 0.01 & $9.30^{\mathrm{y}}$ & $8.83^{\mathrm{z}}$ & 0.02 & 0.01 & $<0.01$ & 0.16 \\
\hline Total FA & $0.81^{\mathrm{b}}$ & $1.25^{\mathrm{a}}$ & $1.25^{\mathrm{a}}$ & $1.24^{\mathrm{a}}$ & 0.02 & $0.92^{\mathrm{z}}$ & $1.35^{\mathrm{y}}$ & 0.03 & $<0.01$ & $<0.01$ & 0.98 \\
\hline 16-carbon FA & $0.15^{\mathrm{c}}$ & $0.52^{\mathrm{a}}$ & $0.34^{\mathrm{b}}$ & $0.37^{\mathrm{b}}$ & 0.01 & $0.30^{\mathrm{z}}$ & $0.39^{\mathrm{y}}$ & 0.02 & $<0.01$ & $<0.01$ & 0.80 \\
\hline 18-carbon FA & $0.66^{\mathrm{c}}$ & $0.72^{\mathrm{b}}$ & $0.88^{\mathrm{a}}$ & $0.87^{\mathrm{a}}$ & 0.02 & $0.62^{\mathrm{z}}$ & $0.95^{\mathrm{y}}$ & 0.03 & $<0.01$ & $<0.01$ & 0.90 \\
\hline \multicolumn{12}{|l|}{ Digestibility, \% } \\
\hline DM & $67.9^{\mathrm{ab}}$ & $68.6^{\mathrm{a}}$ & $67.6^{\mathrm{b}}$ & $68.5^{\mathrm{a}}$ & 0.44 & 68.6 & 67.7 & 0.62 & 0.19 & 0.09 & 0.38 \\
\hline NDF & $44.2^{\mathrm{b}}$ & $45.1^{\mathrm{a}}$ & $42.9^{\mathrm{c}}$ & $45.0^{\mathrm{a}}$ & 0.36 & $46.4^{\mathrm{y}}$ & $41.9^{\mathrm{z}}$ & 0.56 & $<0.01$ & 0.05 & 0.71 \\
\hline Total FA & $78.6^{\mathrm{ab}}$ & $77.4^{\mathrm{b}}$ & $68.2^{\mathrm{c}}$ & $79.4^{\mathrm{a}}$ & 1.52 & $76.3^{\mathrm{y}}$ & $74.2^{\mathrm{z}}$ & 1.31 & 0.03 & $<0.01$ & 0.95 \\
\hline 16-carbon FA & $77.6^{\mathrm{a}}$ & $73.0^{\mathrm{b}}$ & $66.0^{\mathrm{c}}$ & $79.1^{\mathrm{a}}$ & 1.06 & 74.6 & 73.4 & 1.09 & 0.08 & $<0.01$ & 0.02 \\
\hline 18-carbon FA & $79.2^{\mathrm{a}}$ & $79.5^{\mathrm{a}}$ & $72.0^{\mathrm{b}}$ & $79.7^{\mathrm{a}}$ & 1.20 & $79.8^{y}$ & $75.7^{\mathrm{z}}$ & 1.45 & 0.05 & $<0.01$ & 0.29 \\
\hline
\end{tabular}

${ }^{\mathrm{a}-\mathrm{c}}$ For FA treatment effect, means in a row with different superscripts differ $(P<0.05)$. Separation conducted only if treatment effect was $P<$ 0.10 .

${ }^{\mathrm{y}, \mathrm{z}}$ For basal diet effect, means in a row with different superscripts differ $(P<0.05)$. Separation conducted only if treatment effect was $P<0.10$. ${ }^{1} \mathrm{CON}=$ control; PA $=1.5 \%$ of FA supplement blend to provide approximately $80 \%$ of C16:0; PA+SA $=1.5 \%$ of FA supplement blend to provide approximately $40 \%$ of $\mathrm{C} 16: 0+40 \%$ of $\mathrm{C} 18: 0 ; \mathrm{PA}+\mathrm{OA}=1.5 \%$ of $\mathrm{FA}$ supplement blend to provide approximately $45 \%$ of $\mathrm{C} 16: 0+35 \%$ of C18:1 cis-9.

${ }^{2}$ Basal diet includes diets with soyhulls (SH) and diets with whole cottonseed (CS).

${ }^{3} P$-values refer to the ANOVA results for the main effects of basal diet and FA treatment and the interaction between basal diet and FA treatment. 

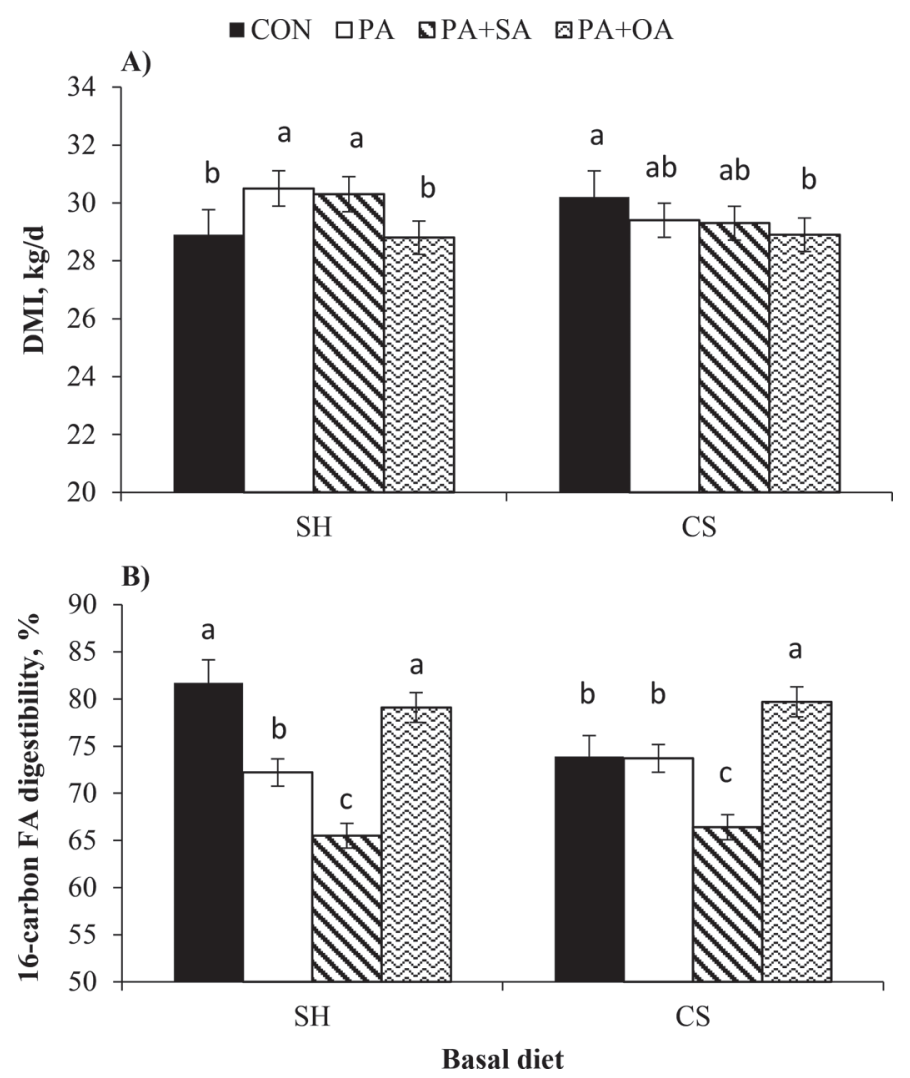

Figure 1. Interaction between basal diet and fatty acid (FA) treatment for (A) DMI and (B) 16-carbon FA digestibility. Significant interactions between basal diet and FA treatments were detected for DMI $(P=0.05)$ and 16 -carbon FA digestibility $(P=0.02)$. Basal diet includes diets with soyhulls ( $\mathrm{SH})$ and diets with whole cottonseed (CS). $\mathrm{CON}=$ control diet; $\mathrm{PA}=1.5 \%$ of FA supplement blend to provide approximately $80 \%$ of $\mathrm{C} 16: 0 ; \mathrm{PA}+\mathrm{SA}=1.5 \%$ of $\mathrm{FA}$ supplement blend to provide approximately $40 \%$ of $\mathrm{C} 16: 0+40 \%$ of $\mathrm{C} 18: 0$; $\mathrm{PA}+\mathrm{OA}=1.5 \%$ of FA supplement blend to provide approximately $45 \%$ of $\mathrm{C} 16: 0+35 \%$ of cis-9 C18:1. Error bars represent SEM. For FA treatment effect, means within basal fat diets with different letters $(\mathrm{a}-\mathrm{c})$ differ $(P<0.05)$.

an interaction between basal diet and FA treatments for milk fat content due to $\mathrm{PA}+\mathrm{OA}$ decreasing fat content compared with the other FA treatments in the $\mathrm{SH}$ diets but not in the CS diets $(P<0.05$; Figure $3 \mathrm{~B})$.

Compared with the $\mathrm{SH}$ diets, the CS diets tended to decrease milk yield and milk lactose yield (both $P$ $=0.10)$ but increased milk fat content $(P<0.05)$ and milk fat yield $(P<0.05)$. There were no differences between $\mathrm{SH}$ and $\mathrm{CS}$ diets for 3.5\% FCM, ECM, feed efficiency $(3.5 \%$ FCM/DMI), milk protein content, and milk protein yield $(P>0.15)$. However, CS diets increased BW change compared with $\mathrm{SH}$ diets $(P<$ $0.05)$.

Compared with CON, all FA treatments increased milk yield $(P<0.05)$. The PA treatment increased milk fat yield compared with other treatments $(P<0.05)$, increased milk fat content compared with $\mathrm{PA}+\mathrm{OA}(P$
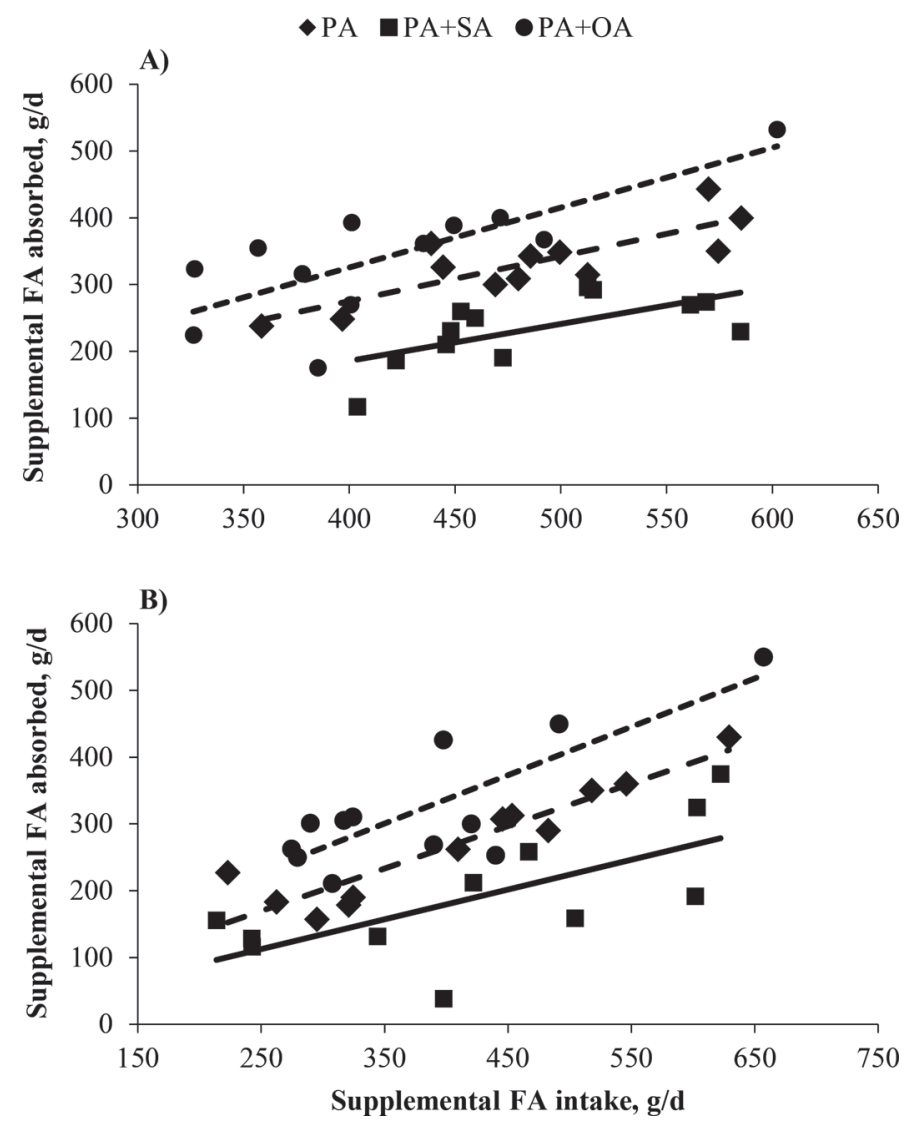

Figure 2. Lucas test to estimate total fatty acid (FA) digestibility of supplemental FA treatments when cows received a basal diet with either (A) soyhulls or (B) whole cottonseed. Digestibility of supplemental FA was estimated by regressing intake of supplemental FA by supplemental FA absorbed. The mean intakes of FA and absorbed FA when cows were fed the control diet were subtracted from the actual intakes of total FA and absorbed FA for each observation (Weiss et al., 2011). PA (long-dashed line) $=1.5 \%$ of FA supplement blend to provide approximately $80 \%$ of $\mathrm{C} 16: 0 ; \mathrm{PA}+\mathrm{SA}$ (solid line) $=1.5 \%$ of FA supplement blend to provide approximately $40 \%$ of $\mathrm{C} 16: 0+40 \%$ of $\mathrm{C} 18: 0 ; \mathrm{PA}+\mathrm{OA}$ (short-dashed line) $=1.5 \%$ of FA supplement blend to provide approximately $45 \%$ of $\mathrm{C} 16: 0+35 \%$ of cis-9 C18:1. The slopes (i.e., digestibility of supplemental fat) for basal diets with soyhulls were $0.64,0.55$, and 0.75 for $\mathrm{PA}, \mathrm{PA}+\mathrm{SA}$, and $\mathrm{PA}+\mathrm{OA}$, respectively, and intercepts were not different from zero $(P>0.55)$. The slopes for basal diets with whole cottonseed were $0.70,0.56$, and 0.81 for PA, $\mathrm{PA}+\mathrm{SA}$, and $\mathrm{PA}+\mathrm{OA}$, respectively, and intercepts were not different from zero $(P>0.64)$.

$<0.05)$, and tended to increase milk fat content compared with $\mathrm{CON}$ and $\mathrm{PA}+\mathrm{SA}(P<0.10)$. As a result, PA increased 3.5\% FCM and ECM compared with CON $(P<0.05)$ and tended to increase it compared with $\mathrm{PA}+\mathrm{SA}$ and $\mathrm{PA}+\mathrm{OA}(P<0.10)$. In addition, $\mathrm{PA}+\mathrm{SA}$ and $\mathrm{PA}+\mathrm{OA}$ tended to increase $3.5 \% \mathrm{FCM}$ and $\mathrm{ECM}$ compared with CON $(P<0.10)$. The PA+OA treatment decreased milk protein content compared with other treatments $(P<0.05)$, whereas $\mathrm{PA}$ and $\mathrm{PA}+\mathrm{SA}$ also decreased milk protein content compared with CON $(P<0.05)$. Additionally, PA tended to increase 
milk protein yield compared with $\mathrm{CON}$ and $\mathrm{PA}+\mathrm{SA}(P$ $<0.10)$. Feed efficiency $(3.5 \% \mathrm{FCM} / \mathrm{DMI}), \mathrm{BW}$, and BCS were not affected by FA treatments $(P>0.10)$. However, PA+OA increased BW change and BCS change compared with other treatments $(P<0.05)$.

\section{Milk FA Concentration and Yield}

Milk FA are derived from 2 sources: $<16$ carbon FA from de novo synthesis in the mammary gland, and $>16$ carbon FA originating from extraction from plasma. Mixed-source FA (C16:0 and cis-9 C16:1) originate from de novo synthesis in the mammary gland and extraction from plasma. No interactions between basal diet and FA treatments were observed with respect to the yields of de novo, mixed, and preformed FA $(P>$ 0.15 ; Table 6$)$. We observed a tendency for an interaction between basal diet and FA treatments for the concentration of de novo milk FA (Table 6; Supplemental Figure S1, https://doi.org/10.3168/jds.2017-13460; $P$ $<0.15)$, which occurred because PA+OA decreased de novo FA concentration compared with $\mathrm{PA}$ and $\mathrm{PA}+\mathrm{SA}$ only in the SH diets $(P<0.10)$. No interaction between basal diet and FA treatments was observed for mixed $(P=0.19)$ and preformed $(P>0.31)$ FA.
Compared with $\mathrm{SH}$ diets, CS diets increased the yield of preformed milk FA $(P<0.05)$ and tended to increase the yield of de novo milk FA $(P<0.10)$. There was no effect of basal diet on the yield of mixed FA $(P=0.97)$. Compared with $\mathrm{SH}$ diets, CS diets increased preformed $(P=0.01)$, decreased mixed $(P<0.05)$, and tended to increase de novo milk FA concentrations $(P<0.10)$.

The PA+OA treatment decreased yield of de novo milk FA compared with $\mathrm{CON}, \mathrm{PA}$, and $\mathrm{PA}+\mathrm{SA}(P$ $<0.05)$ but increased the yield of preformed milk FA compared with CON and PA $(P<0.05)$ and tended to increase it compared with $\mathrm{PA}+\mathrm{SA}(P<0.10)$. The PA treatment increased yield of mixed FA compared with other treatments $(P<0.05)$. Additionally, $\mathrm{PA}+\mathrm{SA}$ tended to increase the yield of mixed FA compared with CON $(P<0.10)$. The PA+SA treatment also increased the yield of preformed milk FA compared with CON $(P$ $<0.05)$. All FA treatments decreased de novo milk FA concentration compared with $\mathrm{CON}(P<0.05)$, with $\mathrm{PA}+\mathrm{OA}$ reducing de novo FA concentration compared with PA and PA+SA $(P<0.05)$. The PA treatment increased mixed FA concentration compared with $\mathrm{CON}, \mathrm{PA}+\mathrm{SA}$, and $\mathrm{PA}+\mathrm{OA}(P<0.05)$. The $\mathrm{PA}+\mathrm{OA}$ treatment increased milk preformed FA concentration compared with $\mathrm{CON}, \mathrm{PA}$, and $\mathrm{PA}+\mathrm{SA}(P<0.05)$.

Table 5. Milk production, milk composition, BW, and BCS for cows fed fatty acid (FA) treatment diets $(\mathrm{n}=24)$

\begin{tabular}{|c|c|c|c|c|c|c|c|c|c|c|c|}
\hline \multirow[b]{2}{*}{ Item } & \multicolumn{4}{|c|}{ FA treatment ${ }^{1}$} & \multicolumn{3}{|c|}{ Basal diet ${ }^{2}$} & \multirow[b]{2}{*}{ SEM } & \multicolumn{3}{|c|}{$P$-value ${ }^{3}$} \\
\hline & $\mathrm{CON}$ & PA & $\mathrm{PA}+\mathrm{SA}$ & $\mathrm{PA}+\mathrm{OA}$ & SEM & $\mathrm{SH}$ & $\mathrm{CS}$ & & $\begin{array}{c}\text { Basal } \\
\text { diet }\end{array}$ & FA & $\begin{array}{c}\text { Basal diet } \\
\times \mathrm{FA}\end{array}$ \\
\hline \multicolumn{12}{|l|}{ Yield, kg/d } \\
\hline Milk & $44.6^{\mathrm{b}}$ & $46.9^{\mathrm{a}}$ & $46.3^{\mathrm{a}}$ & $46.5^{\mathrm{a}}$ & 1.01 & 47.5 & 44.5 & 1.27 & 0.10 & 0.01 & 0.09 \\
\hline $3.5 \% \mathrm{FCM}^{4}$ & $45.2^{\mathrm{b}}$ & $47.8^{\mathrm{a}}$ & $46.8^{\mathrm{ab}}$ & $46.7^{\mathrm{ab}}$ & 0.84 & 46.2 & 47.1 & 0.92 & 0.51 & 0.03 & 0.23 \\
\hline $\mathrm{ECM}^{5}$ & $45.3^{\mathrm{b}}$ & $47.7^{\mathrm{a}}$ & $46.7^{\mathrm{ab}}$ & $46.5^{\mathrm{ab}}$ & 0.82 & 46.3 & 46.8 & 0.91 & 0.69 & 0.05 & 0.23 \\
\hline Fat & $1.60^{\mathrm{b}}$ & $1.70^{\mathrm{a}}$ & $1.64^{\mathrm{b}}$ & $1.64^{\mathrm{b}}$ & 0.04 & $1.58^{\mathrm{z}}$ & $1.71^{\mathrm{y}}$ & 0.04 & 0.05 & 0.01 & 0.22 \\
\hline Protein & 1.42 & 1.47 & 1.45 & 1.43 & 0.02 & 1.46 & 1.42 & 0.03 & 0.43 & 0.12 & 0.19 \\
\hline Lactose & $2.12^{\mathrm{b}}$ & $2.21^{\mathrm{a}}$ & $2.19^{\mathrm{a}}$ & $2.20^{\mathrm{a}}$ & 0.05 & 2.25 & 2.10 & 0.06 & 0.10 & 0.07 & 0.24 \\
\hline \multicolumn{12}{|c|}{ Milk composition, \% } \\
\hline Fat & $3.62^{\mathrm{ab}}$ & $3.69^{\mathrm{a}}$ & $3.60^{\mathrm{ab}}$ & $3.53^{\mathrm{b}}$ & 0.07 & $3.34^{\mathrm{z}}$ & $3.87^{\mathrm{y}}$ & 0.15 & 0.02 & 0.06 & 0.03 \\
\hline Protein & $3.19^{\mathrm{a}}$ & $3.14^{\mathrm{b}}$ & $3.14^{\mathrm{b}}$ & $3.07^{\mathrm{c}}$ & 0.04 & 3.06 & 3.21 & 0.06 & 0.17 & 0.01 & 0.91 \\
\hline Lactose & 4.74 & 4.72 & 4.71 & 4.71 & 0.03 & 4.73 & 4.70 & 0.04 & 0.63 & 0.44 & 0.38 \\
\hline FCM/DMI & 1.54 & 1.60 & 1.57 & 1.62 & 0.03 & 1.56 & 1.60 & 0.03 & 0.46 & 0.14 & 0.31 \\
\hline $\mathrm{BW}, \mathrm{kg}$ & 729 & 732 & 729 & 737 & 15.9 & 726 & 738 & 21.6 & 0.76 & 0.77 & 0.84 \\
\hline BW change, $\mathrm{kg} / \mathrm{d}$ & $0.82^{\mathrm{b}}$ & $0.84^{\mathrm{b}}$ & $0.70^{\mathrm{b}}$ & $1.05^{\mathrm{a}}$ & 0.05 & $0.71^{\mathrm{z}}$ & $1.00^{\mathrm{y}}$ & 0.18 & 0.04 & $<0.01$ & 0.43 \\
\hline $\mathrm{BCS}$ & 3.26 & 3.24 & 3.23 & 3.29 & 0.05 & 3.25 & 3.26 & 0.08 & 0.35 & 0.11 & 0.74 \\
\hline BCS change & $0.07^{\mathrm{b}}$ & $0.07^{\mathrm{b}}$ & $0.04^{\mathrm{b}}$ & $0.11^{\mathrm{a}}$ & 0.02 & 0.07 & 0.10 & 0.03 & 0.12 & 0.04 & 0.85 \\
\hline
\end{tabular}

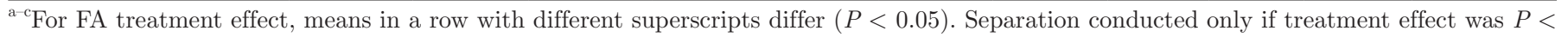
0.10 .

${ }^{\mathrm{y}, \mathrm{z}}$ For basal diet effect, means in a row with different superscripts differ $(P<0.05)$. Separation conducted only if treatment effect was $P<0.10$. ${ }^{1} \mathrm{CON}=$ control; $\mathrm{PA}=1.5 \%$ of $\mathrm{FA}$ supplement blend to provide approximately $80 \%$ of $\mathrm{C} 16: 0 ; \mathrm{PA}+\mathrm{SA}=1.5 \%$ of $\mathrm{FA}$ supplement blend to pro-

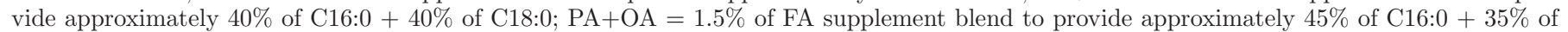
C18:1 cis-9.

${ }^{2}$ Basal diet includes diets with soyhulls (SH) and diets with whole cottonseed (CS).

${ }^{3} P$-values refer to the ANOVA results for the main effects of basal diet and FA treatment and the interaction between basal diet and FA treatment.

${ }^{4} 3.5 \% \mathrm{FCM}=(0.4324 \times \mathrm{kg}$ of milk $)+(16.216 \times \mathrm{kg}$ of milk fat $)$.

${ }^{5} \mathrm{ECM}=(0.327 \times \mathrm{kg}$ of milk $)+(12.95 \times \mathrm{kg}$ of milk fat $)+(7.20 \times \mathrm{kg}$ of milk protein $)$. 

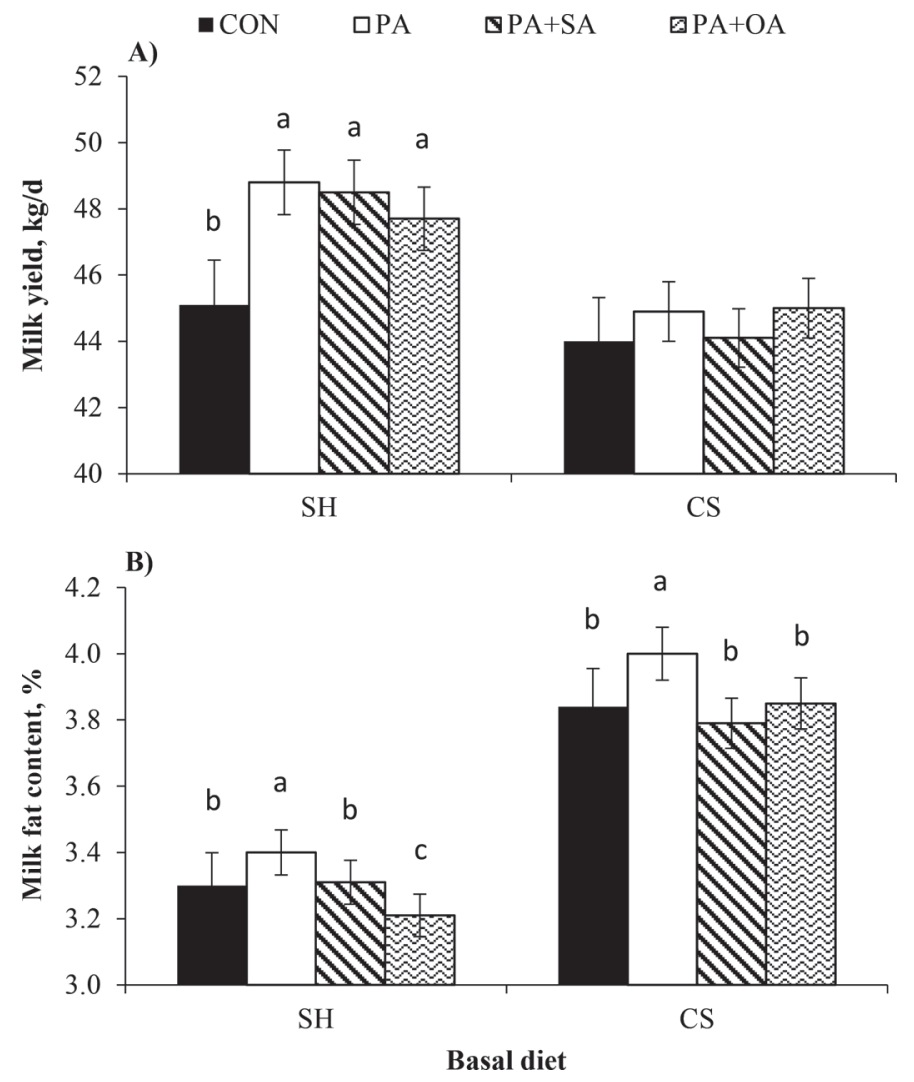

Figure 3. Interaction between basal diet and fatty acid (FA) treatment for (A) milk yield and (B) milk fat content for cows fed the different combinations of FA treatments in both basal diets. Significant interactions between basal diet and FA treatments were detected for milk yield $(P=0.09)$ and milk fat content $(P=0.03)$. Basal diet includes diets with soyhulls ( $\mathrm{SH}$ ) and diets with whole cottonseed (CS). $\mathrm{CON}=$ control diet; $\mathrm{PA}=1.5 \%$ of $\mathrm{FA}$ supplement blend to provide approximately $80 \%$ of $\mathrm{C} 16: 0 ; \mathrm{PA}+\mathrm{SA}=1.5 \%$ of $\mathrm{FA}$ supplement blend to provide approximately $40 \%$ of $\mathrm{C} 16: 0+40 \%$ of $\mathrm{C} 18: 0$; $\mathrm{PA}+\mathrm{OA}=$ $1.5 \%$ of FA supplement blend to provide approximately $45 \%$ of C16:0 $+35 \%$ of cis-9 C18:1. Error bars represent SEM. For FA treatment effect, means within basal fat diets with different letters $(\mathrm{a}-\mathrm{c})$ differ $(P<0.05)$.

\section{Insulin and Energy Partitioning}

We did not observe any interactions between basal diet and FA treatments for insulin and variables related to energy partitioning (Table 7). There was no effect of basal diet on insulin, milk energy output, or energy used for maintenance (all $P>0.10$ ). However, compared with $\mathrm{SH}$ diets, $\mathrm{CS}$ diets increased $\mathrm{NE}_{\mathrm{L}}$ intake $(P$ $<0.05)$ and tended to increase energy stored as body reserves $(P<0.10)$. When considering the partitioning of energy (as percentage of energy intake), basal diet did not change the percentage of energy partitioned to milk $(P>0.10)$. However, compared with SH diets, CS diets increased energy partitioning toward body reserves $(P$ $<0.05)$ and decreased energy used for maintenance $(P$ $<0.05)$.
The $\mathrm{PA}+\mathrm{OA}$ treatment increased plasma insulin concentration compared with other treatments $(P<$ $0.05)$. The PA treatment increased milk energy output compared with CON $(P<0.05)$ and tended to increase it compared with $\mathrm{PA}+\mathrm{SA}$ and $\mathrm{PA}+\mathrm{OA}(P<0.10)$. In addition, $\mathrm{PA}+\mathrm{SA}$ and $\mathrm{PA}+\mathrm{OA}$ tended to increase milk energy output compared with $\mathrm{CON}(P<0.10)$. The $\mathrm{PA}+\mathrm{OA}$ treatment also increased energy partitioned to body reserves compared with $\mathrm{PA}+\mathrm{SA}(P<0.05)$ and tended to increase it compared with CON and PA $(P<$ $0.10)$. The PA treatment increased energy partitioning (as percentage of energy intake) toward milk compared with $\mathrm{CON}$ and $\mathrm{PA}+\mathrm{OA}(P<0.05)$ and tended to increase it compared with PA+SA $(P<0.10)$. Similarly, $\mathrm{PA}+\mathrm{SA}$ increased energy partitioning toward milk compared with $\mathrm{PA}+\mathrm{OA}(P<0.05)$. In contrast, $\mathrm{PA}+\mathrm{OA}$ increased energy partitioned to body reserves compared with PA $(P<0.05)$ and PA+SA $(P<0.05)$ and tended to increase it compared with $\mathrm{CON}(P<0.10)$.

\section{DISCUSSION}

Recently, the effects of individual FA on digestibility, metabolism, and production responses of dairy cows have received renewed attention. Typically, C16:0, C18:0, and cis-9 C18:1 are the most abundant FA found in commercially available fat supplements fed to dairy cows. Also, these FA normally compose the majority of FA present in milk fat, ranging from 20 to 40,9 to 14, and 20 to $30 \mathrm{~g} / 100 \mathrm{~g}$ of FA for C16:0, C18:0, and cis-9 C18:1, respectively (Jensen, 2002). In our study, we hypothesized that the response to combinations of these 3 FA may be affected by the addition of whole cottonseed due to its high content of long-chain FA. However, although we did not measure rumen fermentation parameters, it is important to consider possible differences in fiber effectiveness and rumination activity between soyhulls and whole cottonseed that also may have affected our results. Importantly, both the SH and CS basal diets in our study represented diets that can typically be fed to high-producing cows under commercial conditions, including ingredients that are widely available to dairy farmers.

The effect of fat supplements on DMI is variable and usually depends on the type of fat being fed (Rabiee et al., 2012). When fed at up to $3 \%$ of dietary DM, saturated FA supplementation mostly results in no change in DMI (Palmquist and Jenkins, 1980). In a meta-regression of 29 treatment means compiled from the literature, Allen (2000) observed that hydrogenated saturated FA supplements did not affect DMI. This is supported by our results with the PA and PA+SA treatments, in which no differences in DMI were observed compared with CON. Although some studies with 
Table 6. Fatty acid (FA) concentration and yield by source of milk FA for cows fed treatment diets $(\mathrm{n}=24)$

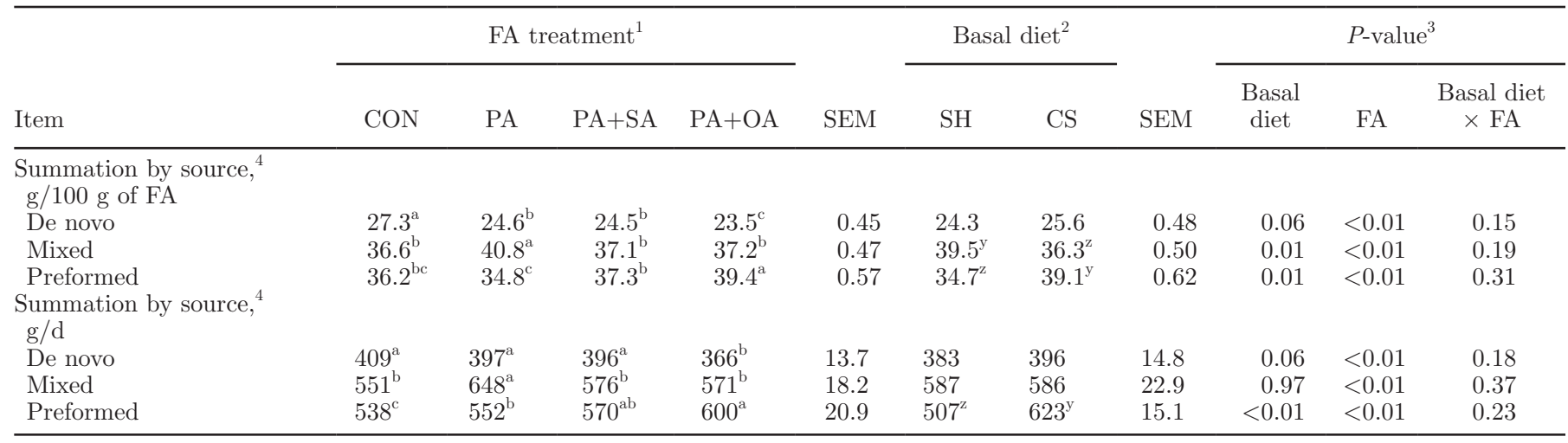

${ }^{a-c}$ For FA treatment effect, means in a row with different superscripts differ $(P<0.05)$. Separation conducted only if treatment effect was $P<$ 0.10 .

${ }^{\mathrm{y}, \mathrm{z}}$ For basal diet effect, means in a row with different superscripts differ $(P<0.05)$. Separation conducted only if treatment effect was $P<0.10$. ${ }^{1} \mathrm{CON}=$ control; $\mathrm{PA}=1.5 \%$ of FA supplement blend to provide approximately $80 \%$ of $\mathrm{C} 16: 0 ; \mathrm{PA}+\mathrm{SA}=1.5 \%$ of $\mathrm{FA}$ supplement blend to provide approximately $40 \%$ of $\mathrm{C} 16: 0+40 \%$ of $\mathrm{C} 18: 0 ; \mathrm{PA}+\mathrm{OA}=1.5 \%$ of FA supplement blend to provide approximately $45 \%$ of $\mathrm{C} 16: 0+35 \%$ of C18:1 cis-9

${ }^{2}$ Basal diet includes diets with soyhulls (SH) and diets with whole cottonseed (CS).

${ }^{3} P$-values refer to the ANOVA results for the main effects of basal diet and FA treatment and the interaction between basal diet and FA treatment.

${ }^{4}$ De novo FA originate from mammary de novo synthesis ( $<16$ carbons), preformed FA originate from extraction from plasma ( $>16$ carbons), and mixed FA originate from both sources (C16:0 plus cis-9 C16:1). Concentrations and yields of individual FA are reported in Supplemental Tables S1 and S2, respectively (https://doi.org/10.3168/jds.2017-13460).

highly enriched $(\geq 85 \%)$ sources of $\mathrm{C} 16: 0$ and C18:0 have reported decreased DMI (Lock et al., 2013; Rico et al., 2014a), others reported that DMI was not reduced (Piantoni et al., 2013, 2015; de Souza et al., 2016; Boerman et al., 2017) when fed at 1.5 to $2.3 \%$ of diet DM compared with a control (no supplemental FA) diet. We observed that $\mathrm{PA}+\mathrm{OA}$ decreased DMI compared with $\mathrm{CON}$ in the $\mathrm{CS}$ diets but not in the SH diets, which is likely related to the greater intake and duodenal flow of unsaturated FA on the CS diet. The hypophagic effect

Table 7. Insulin concentration, calculated energy, and energy partitioning toward milk, body tissues, and maintenance for cows fed treatment $\operatorname{diets}(\mathrm{n}=24)$

\begin{tabular}{|c|c|c|c|c|c|c|c|c|c|c|c|}
\hline Item & \multicolumn{4}{|c|}{ FA treatment ${ }^{1}$} & SEM & \multicolumn{2}{|c|}{ Basal diet ${ }^{2}$} & SEM & \multicolumn{3}{|c|}{$P$-value ${ }^{3}$} \\
\hline $\mathrm{NE}_{\mathrm{L}}$ intake & $49.4^{\mathrm{b}}$ & $51.0^{\mathrm{a}}$ & $50.1^{\mathrm{b}}$ & $50.9^{\mathrm{a}}$ & 0.65 & $50.2^{\mathrm{z}}$ & $51.4^{\mathrm{y}}$ & 0.55 & 0.04 & $<0.01$ & 0.36 \\
\hline Milk & $31.2^{\mathrm{b}}$ & $32.8^{\mathrm{a}}$ & $32.0^{\mathrm{ab}}$ & $31.9^{\mathrm{ab}}$ & 0.55 & 31.7 & 32.1 & 0.79 & 0.63 & 0.07 & 0.27 \\
\hline \multicolumn{12}{|c|}{$\begin{array}{l}\text { Partitioning, \% of energy } \\
\text { intake }\end{array}$} \\
\hline Milk & $63.1^{\mathrm{bc}}$ & $64.4^{\mathrm{a}}$ & $63.6^{\mathrm{ab}}$ & $62.4^{\mathrm{c}}$ & 0.63 & 63.1 & 63.6 & 0.98 & 0.25 & 0.09 & 0.45 \\
\hline Body tissue gain & $12.6^{\mathrm{ab}}$ & $11.8^{\mathrm{b}}$ & $11.5^{\mathrm{b}}$ & $13.4^{\mathrm{a}}$ & 0.61 & $11.2^{\mathrm{z}}$ & $13.4^{\mathrm{y}}$ & 0.65 & 0.02 & 0.07 & 0.58 \\
\hline Maintenance & $24.3^{\mathrm{ab}}$ & $23.9^{\mathrm{b}}$ & $24.9^{\mathrm{a}}$ & $24.3^{\mathrm{ab}}$ & 0.58 & $25.3^{\mathrm{y}}$ & $23.0^{\mathrm{z}}$ & 0.65 & 0.05 & 0.10 & 0.87 \\
\hline
\end{tabular}

${ }^{\mathrm{a}-\mathrm{c}}$ For fatty acid (FA) treatment effect, means in a row with different superscripts differ $(P<0.05)$. Separation conducted only if treatment effect was $P<0.10$.

${ }^{\mathrm{y}, \mathrm{z}}$ For basal diet effect, means in a row with different superscripts differ $(P<0.05)$. Separation conducted only if treatment effect was $P<0.10$. ${ }^{1} \mathrm{CON}=$ control; $\mathrm{PA}=1.5 \%$ of $\mathrm{FA}$ supplement blend to provide approximately $80 \%$ of $\mathrm{C} 16: 0 ; \mathrm{PA}+\mathrm{SA}=1.5 \%$ of $\mathrm{FA}$ supplement blend to provide approximately $40 \%$ of $\mathrm{C} 16: 0+40 \%$ of $\mathrm{C} 18: 0 ; \mathrm{PA}+\mathrm{OA}=1.5 \%$ of FA supplement blend to provide approximately $45 \%$ of $\mathrm{C} 16: 0+35 \%$ of C18:1 cis-9.

${ }^{2}$ Basal diet includes diets with soyhulls (SH) and diets with whole cottonseed (CS).

${ }^{3} P$-values refer to the ANOVA results for the main effects of basal diet and FA treatment and the interaction between basal diet and FA treatment. 
of feeding fat seems to be more pronounced for unsaturated than for saturated FA supplements (Harvatine and Allen, 2006), with DMI decreasing linearly as the degree of unsaturation increases (Drackley et al., 1992; Pantoja et al., 1994) and the chain length of FA infused into the abomasum increases (Drackley et al., 1992). The more pronounced decrease in DMI for unsaturated FA is likely mediated in part by increased secretion of gut peptides related to satiety (i.e., cholecystokinin and glucagon-like peptide-1; Relling and Reynolds, 2007; Bradford et al., 2008). Although PA+OA mainly increased cis-9 C18:1, intake of cis-9,cis-12 C18:2 was also increased in this treatment; the increase, however, was more pronounced for the CS diets. Further research is needed to determine whether a higher amount of unsaturated FA or a higher amount of a specific FA is related to reduced feed intake.

The PA treatment reduced 16-carbon FA digestibility but did not affect total FA digestibility compared with CON. The digestibility of FA usually decreases as FA intake increases (Palmquist, 1991; Boerman et al., 2015b). Although Rico et al. (2014a) reported that feeding a highly enriched C16:0 supplement (85\% C16:0; $2 \%$ diet DM) had positive effects on 16-carbon and total FA digestibility, other studies have observed reductions in FA digestibility when feeding similar supplements at the same dietary level (Piantoni et al., 2013; de Souza et al., 2017). Interestingly, we observed an interaction between basal diet and FA treatment for 16-carbon FA digestibility, with the PA treatment decreasing 16-carbon FA digestibility only in the SH diet. Similarly, Rico et al. (2017) observed that 16-carbon FA digestibility was reduced when feeding a C16:0 supplement (89\% C16:0) to a greater extent in a soyhulls basal diet rather than a whole cottonseed basal diet. Although total flow of FA at the duodenum affects FA digestibility (Boerman et al., 2015a), these findings support the hypothesis that the profile of FA entering the duodenum is a critical factor affecting FA digestibility. Furthermore, PA+OA increased digestibilities of 16-carbon and total FA compared with $\mathrm{PA}$ and $\mathrm{PA}+\mathrm{SA}$ and increased 18-carbon FA digestibility compared with $\mathrm{PA}+\mathrm{SA}$, which may be attributable to the greater solubility of UFA facilitating transfer of FA to micelles (Freeman, 1969) and rapid uptake and re-esterification in enterocytes compared with SFA (Ockner et al., 1972).

The PA+SA treatment markedly decreased FA digestibility by reducing digestibilities of 16 -carbon and 18-carbon FA. Feeding C18:0-enriched FA supplements has been shown to decrease FA digestibility in dairy cows (Piantoni et al., 2015; Boerman et al., 2017) and sheep (Toral et al., 2016). Similarly, Chamberlain and DePeters (2017) observed that increasing the proportion of C18:0 to C16:0 in supplemental fat (2\% of diet
DM) reduced total FA digestibility in dairy cows. Interestingly, we observed that even though PA had a higher intake of 16-carbon FA compared with $\mathrm{PA}+\mathrm{SA}$, 16-carbon FA digestibility decreased 3 times more with $\mathrm{PA}+\mathrm{SA}$ compared with PA. These results suggest that, more important than the total amount of FA reaching the intestine, the profile of FA reaching the intestine is most likely the major factor that affects digestibility. In a recent meta-analysis, we observed no reduction in FA digestibility when the duodenal flow of C16:0 increased up to $500 \mathrm{~g} / \mathrm{d}$, whereas increasing the duodenal flow of C18:0 linearly reduced FA digestibility (Boerman et al., 2015a). Potential reasons for the reduction in FA digestibility include a limitation in lysolecithin secretion reducing the flux of FA into micelles (Boerman et al., 2015a) and a possible saturation of absorptive sites in the intestine (Glasser et al., 2008b). Piantoni et al. (2015) postulated that the low digestibility of the C18:0-enriched FA supplement used in their study could have resulted from the greater prill size of the FA supplement fed. This explanation is likely not supported by our results because the major supplement in the PA+SA treatment (Energy Booster 100) had the smallest prill size among the FA supplements used to make our treatment FA blends. Additionally, the particle size of the FA supplements used in our study is similar to those used by de Souza et al. (2017) for a C16:0-enriched supplement, in which prill size had minor effects on FA digestibility. Also, Boerman et al. (2017) suggested that the lower digestibility of C18:0-enriched FA supplements may be related to their higher melting point compared with other supplements. However, in our study we observed greater total FA digestibility for PA compared with PA+SA despite the major supplement in the PA+SA treatment (Energy Booster 100) having a lower melting point than the major supplement in the PA treatment (Bergafat F-100). It is possible that other factors related to the physical structure of the FA supplements may be associated with the reduction in digestibility. Additional research to understand reasons for the pronounced reduction in FA digestibility with FA supplements containing C18:0 and how this may be overcome is required.

The NDF digestibility increased with PA in comparison with $\mathrm{CON}$ and $\mathrm{PA}+\mathrm{SA}$. These results agree with previous studies feeding highly enriched C16:0 supplements (Warntjes et al., 2008; de Souza et al., 2016; Rico et al., 2017). The increase in NDF digestibility with C16:0 supplements may be associated with an increase in retention time driven by an increase in cholecystokinin secretion (Piantoni et al., 2013). The increase in NDF digestibility with PA+OA is likely also associated with the decrease in DMI in this treatment. In a recent meta-analysis, Weld and Armentano (2017) observed 
that Ca salts of palm FA did not affect NDF digestibility. Due to the observed increases in NDF digestibility and no negative effects on FA digestibility, both PA and $\mathrm{PA}+\mathrm{OA}$ increased $\mathrm{DM}$ digestibility compared with $\mathrm{CON}$. The PA+SA treatment reduced digestibilities of $\mathrm{NDF}$ and FA, which resulted in this treatment reducing DM digestibility compared with $\mathrm{PA}$ and $\mathrm{PA}+\mathrm{OA}$. Similarly, increasing the proportion of $\mathrm{C} 18: 0$ to $\mathrm{C} 16: 0$ in a supplemental fat reduced OM digestibility in dairy cows (Chamberlain and DePeters, 2017).

Interestingly, we observed that the increase in milk fat yield with CS diets was a result of an increase in the yield of preformed FA and de novo milk FA. These results are supported by a meta-analysis that highlighted the interdependence between the yields of 18-carbon and de novo FA in milk, proposing that milk lipid synthesis in the mammary gland is dependent on the simultaneous supply of short- or medium-chain FA and long-chain FA (Glasser et al., 2008a). In our study, the increase in preformed FA was expected because of the greater intake of long-chain FA in CS diets. Milk fat yield also increased for PA compared with $\mathrm{CON}$ $(+100 \mathrm{~g} / \mathrm{d}), \mathrm{PA}+\mathrm{SA}(+60 \mathrm{~g} / \mathrm{d})$, and $\mathrm{PA}+\mathrm{OA}(+60$ $\mathrm{g} / \mathrm{d})$. These findings agree with previous studies feeding supplements highly enriched with C16:0 compared with a control (no supplemental FA) diet (Lock et al., 2013; Piantoni et al., 2013; Rico et al., 2017) or a diet containing a C18:0-enriched supplement (Rico et al., 2014b). A higher preference (8- to 10-fold) was shown for $\mathrm{C} 16: 0$ as a substrate for glycerol-3-phosphate acyltransferase, which esterifies FA at the sn-1 position to start triglyceride synthesis, than for $\mathrm{C} 18: 0$ or cis-9 C18:1 (Kinsella and Gross, 1973). The FA C16:0 can be esterified at both the sn- 1 and sn-2 positions (Jensen, 2002). Tzompa-Sosa et al. (2014) suggested that an increase in availability of C16:0 for lipid synthesis in mammary epithelial cells may increase the activity of glycerol-3-phosphate acyltransferase in the mammary gland, increasing the proportion of $\mathrm{C} 16: 0$ acylated at sn- 1 at the expense of sn-2. Other FA counterbalance the decrease in the amount of this FA at sn-2. Overall, this hypothesis could explain our finding that PA increased the yield of mixed-source FA without reducing the yield of de novo and preformed FA not only by increasing triglyceride synthesis but also by changing the FA interpositional distribution in the triglyceride. However, this hypothesis needs to be further evaluated to determine whether this is the mechanism by which C16:0 increases milk fat yield. The FAYR for C16:0 + cis-9 C16:1 was 19.5, 7.5, and $6.5 \%$ for $\mathrm{PA}, \mathrm{PA}+\mathrm{SA}$, and PA+ OA, respectively. For PA+SA the FAYR was $3.1 \%$ for $\mathrm{C} 18: 0$ and $15.0 \%$ for $\mathrm{C} 18: 0+$ cis-9 $\mathrm{C} 18: 1$. For PA+OA the FAYR was $18.5 \%$ for cis-9 $\mathrm{C} 18: 1$ and 20.7\% for C18:0 + cis-9 C18:1. Transfer efficiency from diet to milk fat has ranged from 16 to $24 \%$ in studies feeding C16:0-enriched supplements (Lock et al., 2013; Piantoni et al., 2013) and from 3 to $8 \%$ in studies feeding C18:0-enriched supplements (Piantoni et al., 2015; Boerman et al., 2017).

We observed that the CS diets increased $\mathrm{NE}_{\mathrm{L}}$ intake compared with the SH diets. However, because milk energy output was not different between SH and CS diets, the additional energy intake from CS diets was partitioned to body reserves, which supports our initial hypothesis that if the amount of FA surpasses mammary gland capacity, these might be redirected to other tissues. We observed that among the FA treatments, $\mathrm{PA}+\mathrm{OA}$ increased $\mathrm{BW}$ and $\mathrm{BCS}$ change. The $\mathrm{PA}+\mathrm{OA}$ treatment provided a higher load of UFA in the diet, which likely overcame normal rumen biohydrogenation capacity and altered biohydrogenation pathways. Although PA+OA did not alter milk fat yield compared with CON, this treatment reduced milk fat content and the yield of de novo milk FA while increasing trans-10 C18:1 content in milk fat, suggesting that PA+OA induced a mild milk fat depression situation. Boerman et al. (2015b) observed a positive correlation between milk fat trans-10 C18:1 content and change in BCS; however, milk trans-10 C18:1 content was not associated with milk fat yield. This is likely associated with repartitioning of energy by reducing milk energy output and increasing body fat reserves. Harvatine et al. (2009) reported that during abomasal infusions of trans-10, cis-12 C18:2, there was a downregulation of lipogenic enzymes in mammary tissue and an increase in the expression of lipogenic enzymes in adipose tissue. Conversely, Urrutia and Harvatine (2017) observed reduced lipogenic capacity of adipose tissue explants without changes in gene expression of key lipogenic enzymes during $4 \mathrm{~d}$ of trans-10,cis-12 C18:2 infusion. In our study we did not detect levels of trans-10, cis-12 C18:2 in milk fat for most of our samples, but it is important to consider that other FA produced as intermediates during rumen biohydrogenation have been shown to reduce milk fat (Bauman et al., 2011) and potentially may be involved with energy partitioning. Importantly, we also observed that $\mathrm{PA}+\mathrm{OA}$ increased plasma insulin compared with the other treatments. Previous studies using rats as a model have observed that free FA including oleic acid may stimulate insulin secretion from pancreatic $\beta$-cells (Itoh et al., 2003; Fujiwara et al., 2005), though to our knowledge this has not been studied in cows. Insulin is an antilipolytic hormone, and elevated insulin concentrations may reduce lipolysis or increase lipogenesis in adipose tissue (Vernon, 2005). Therefore, the effect of $\mathrm{PA}+\mathrm{OA}$ on energy partitioning to body reserves could be linked to increased insulin concentrations or production of biohydrogenation intermediates. Also, it 
is important to point out that our design used 21-d periods, and changes in BW in short-term studies may be confounded by differences in gut fill between diets (Weiss et al., 2011). The association between changes in biohydrogenation pathways and allocation of energy across different tissues as well as changes in energy partitioning driven by fat supplementation in long-term studies deserves further attention.

To our knowledge, few studies were designed to evaluate the effects of different FA ratios on the production responses of dairy cows. Loften et al. (2014) reviewed the metabolism of $\mathrm{C} 16: 0$ and C18:0 in lactating dairy cows and suggested that feeding a combination of these FA is needed to optimize their utilization for milk production and overall performance of the dairy cow. In contrast, we found no support for this theory in our study because the $\mathrm{PA}+\mathrm{SA}$ treatment reduced nutrient digestibility and reduced $\mathrm{NE}_{\mathrm{L}}$ intake compared with the other FA treatments. This is likely associated with the observed effect on FA digestibility results because we estimated (Lucas plot) that the PA+SA supplement had lower digestibility than the other FA supplements. Furthermore, we observed that the PA treatment increased milk energy output and energy partitioning toward milk, whereas the $\mathrm{PA}+\mathrm{OA}$ increased energy allocated to BW and the partitioning of energy to BW compared with $\mathrm{PA}+\mathrm{SA}$. This may suggest that C16:0 and cis-9 C18:1 are able to alter energy partitioning between the mammary gland and adipose tissue, which may allow for different FA supplements to be used in different situations according to the metabolic priority of dairy cows and management needs. Further research is needed to confirm these results in cows at different stages of lactation or other physiological conditions.

\section{CONCLUSIONS}

Diets with whole cottonseed increased milk fat yield because of a greater incorporation of preformed FA into milk fat. Also, they increased energy partitioning to BW without reducing milk energy output. Among the combinations of $\mathrm{C} 16: 0, \mathrm{C} 18: 0$, and cis-9 C18:1 evaluated, FA supplements with more C16:0 increased energy output in milk, whereas FA supplements with more cis-9 C18:1 increased energy storage in BW. Increasing C18:0 in an FA supplement reduced nutrient digestibility and did not increase energy intake, which most likely explains its lower performance compared with the other FA treatments.

\section{ACKNOWLEDGMENTS}

We acknowledge the Michigan Alliance for Animal Agriculture (East Lansing) and Al Ames (NutriLinx,
Burlington, VT) for financial support of this study; we also acknowledge $\mathrm{Al}$ Ames for donation of the fat supplements. We acknowledge R. J. Tempelman (Department of Animal Science, Michigan State University, East Lansing) for the helpful discussion with statistical analysis as well as Y. Sun, J. L. Garver, S. Schmidt, M. Western, K. Wu, K. Spaans, J. L. Spaans, and T. N. Bryant (all in the Department of Animal Science, Michigan State University) and the staff of the Michigan State University Dairy Cattle Teaching and Research Center for their assistance in this experiment. Jonas de Souza was supported by a PhD fellowship from Coordenação de Aperfoiçamento de Pessoal de Nivel Superior (CAPES) from the Brazilian Ministry of Education (Brasilia, DF, Brazil).

\section{REFERENCES}

Allen, M. S. 2000. Effects of diet on short-term regulation of feed intake by lactating dairy cattle. J. Dairy Sci. 83:1598-1624.

AOAC. 1990. Official Methods of Analysis. 15th ed. Vol. 2. AOAC International, Arlington, VA.

AOCS. 2013. Official Methods and Recommended Practices of the AOCS. 6th ed. Vol. 3. AOCS International, Urbana, IL.

Bauman, D. E., K. J. Harvatine, and A. L. Lock. 2011. Nutrigenomics, rumen-derived bioactive fatty acids, and the regulation of milk fat synthesis. Annu. Rev. Nutr. 31:299-319.

Boerman, J. P., J. de Souza, and A. L. Lock. 2017. Milk production and nutrient digestibility responses to increasing levels of stearic acid supplementation of dairy cows. J. Dairy Sci. 100:2729-2738.

Boerman, J. P., J. L. Firkins, N. R. St-Pierre, and A. L. Lock. 2015a. Intestinal digestibility of long-chain fatty acids in lactating dairy cows: A meta-analysis and meta regression. J. Dairy Sci. 98:88898903.

Boerman, J. P., S. B. Potts, M. J. VandeHaar, and A. L. Lock. 2015b. Effects of partly replacing dietary starch with fiber and fat on milk production and energy partitioning. J. Dairy Sci. 98:7264-7276.

Bradford, B. J., K. J. Harvatine, and M. S. Allen. 2008. Dietary unsaturated fatty acids increased plasma glucagon-like peptide-1 and cholecystokinin and may decrease premeal ghrelin in lactating dairy cows. J. Dairy Sci. 91:1443-1450.

Chamberlain, M. B., and E. J. DePeters. 2017. Impacts of feeding lipids supplements high in palmitic acid or stearic acid on performance of lactating dairy cows. J. Appl. Anim. Res. 45:126-135.

Clark, P. W., and L. E. Armentano. 1993. Effectiveness of neutral detergent fiber in whole cottonseed and dried distillers grains compared with alfalfa haylage. J. Dairy Sci. 76:2644-2650.

de Souza, J., J. L. Garver, C. L. Preseault, and A. L. Lock. 2017. Effects of prill size of a palmitic acid-enriched fat supplement on yield of milk and milk components and nutrient digestibility of dairy cows. J. Dairy Sci. 100:379-384.

de Souza, J., C. L. Preseault, and A. L. Lock. 2016. Short communication: Lactational responses to palmitic acid supplementation when replacing soyhulls or dry ground corn. J. Dairy Sci. 99:1945-1950.

Douglas, G. N., J. Rehage, A. D. Beaulieu, A. O. Bahaa, and J. K. Drackley. 2007. Prepartum nutrition alters fatty acid composition in plasma, adipose tissue, and liver lipids of periparturient dairy cows. J. Dairy Sci. 90:2941-2959.

Drackley, J. K., T. H. Klusmeyer, A. M. Trusk, and J. H. Clark. 1992 Infusion of long-chain fatty acids varying in saturation and chain length into the abomasum of lactating dairy cows. J. Dairy Sci. 75:1517-1526

Freeman, C. P. 1969. Properties of fatty acids in dispersions of emulsified lipid and bile salt and the significance of these properties in fat absorption in the pig and the sheep. Br. J. Nutr. 23:249-263. 
Fujiwara, K., F. Maekawa, and T. Yada. 2005. Oleic acid interacts with GPR40 to induce $\mathrm{Ca}^{2+}$ signaling in rat islet beta-cells: Mediation by PLC and L-type $\mathrm{Ca}^{2+}$ channel and link to insulin release. Am. J. Physiol. Endocrinol. Metab. 289:E670-E677.

Glasser, F., A. Ferlay, M. Doreau, P. Schmidely, D. Sauvant, and Y. Chilliard. 2008a. Long-chain fatty acid metabolism in dairy cows: A meta-analysis of milk fatty acid yield in relation to duodenal flows and de novo synthesis. J. Dairy Sci. 91:2771-2785.

Glasser, F., P. Schmidely, D. Sauvant, and M. Doreau. 2008b. Digestion of fatty acids in ruminants: A meta-analysis of flows and variation factors: 2. C18 fatty acids. Animal 2:691-704.

Goering, H. K., and P. J. Van Soest. 1970. Forage Fiber Analysis (Apparatus, Reagents, Procedures, and Some Applications). Agricultural handbook no. 379. USDA Agricultural Research Service, Washington, DC.

Harrison, J. H., R. L. Kincaid, J. P. McNamara, S. Waltner, K. A. Loney, R. E. Riley, and J. D. Cronrath. 1995. Effect of whole cottonseeds and calcium salts of long-chain fatty acids on performance of lactating dairy cows. J. Dairy Sci. 78:181-193.

Harvatine, K. J., and M. S. Allen. 2006. Effects of fatty acid supplements on milk yield and energy balance of lactating dairy cows. J. Dairy Sci. 89:1081-1091.

Harvatine, K. J., J. W. Perfield, and D. E. Bauman. 2009. Expression of enzymes and key regulators of lipid synthesis is upregulated in adipose tissue during CLA-induced milk fat depression in dairy cows. J. Nutr. 139:849-854.

Itoh, Y., Y. Kawamata, M. Harada, M. Kobayashi, R. Fujii, S. Fukusumi, K. Ogi, M. Hosoya, Y. Tanaka, H. Uejima, H. Tanaka, M. Maruyama, R. Satoh, S. Okubo, H. Kizawa, H. Komatsu, F. Matsumura, Y. Noguchi, T. Shinohara, S. Hinuma, Y. Fujisawa, and M. Fujino. 2003. Free fatty acids regulate insulin secretion from pancreatic $\beta$ cells through GPR40. Nature 422:173-176.

Jensen, R. G. 2002. The composition of bovine milk lipids: January 1995 to December 2000. J. Dairy Sci. 85:295-350.

Kinsella, J. E., and M. Gross. 1973. Palmitic acid and initiation of mammary glyceride synthesis via phosphatidic acid. Biochim. Biophys. Acta 316:109-113.

Kutner, M. H., C. J. Nachtsheim, J. Neter, and W. Li. 2005. Applied Linear Statistical Models. 5th ed. McGraw Hill, New York, NY.

Lock, A. L., C. L. Preseault, J. E. Rico, K. E. DeLand, and M. S. Allen. 2013. Feeding a C16:0-enriched fat supplement increased the yield of milk fat and improved feed efficiency. J. Dairy Sci. 96:6650-6659.

Loften, J. R., J. G. Linn, J. K. Drackley, T. C. Jenkins, C. G. Soderholm, and A. F. Kertz. 2014. Invited review: Palmitic and stearic acid metabolism in lactating dairy cows. J. Dairy Sci. 97:46614674.

Moreira, V. R., L. D. Satter, and B. Harding. 2004. Comparison of conventional linted cottonseed and mechanically delinted cottonseed in diets for dairy cows. J. Dairy Sci. 87:131-138.

NRC. 2001. Nutritional Requirements of Dairy Cattle. 7th rev. ed. Natl. Acad. Sci., Washington, DC.

Ockner, R. K., J. P. Pittman, and J. L. Yager. 1972. Differences in the intestinal absorption of saturated and unsaturated long chain fatty acids. Gastroenterology 62:981-992.

Palmquist, D. L. 1991. Influence of source and amount of dietary fat on digestibility in lactating cows. J. Dairy Sci. 74:1354-1360.

Palmquist, D. L. 2006. Milk fat: Origin of fatty acids and influence of nutritional factors thereon. Pages 43-92 in Advanced Dairy Chemistry. Volume 2: Lipids, 3rd ed. P. F. Fox and P. L. H. McSweeney, ed. Springer, New York, NY.
Palmquist, D. L., and T. C. Jenkins. 1980. Fat in lactation rations. J. Dairy Sci. 63:1-14

Pantoja, J., J. L. Firkins, M. L. Eastridge, and B. L. Hull. 1994. Effects of fat saturation and source of fiber on site of nutrient digestion and milk production. J. Dairy Sci. 77:2341-2356.

Piantoni, P., A. L. Lock, and M. S. Allen. 2013. Palmitic acid increased yields of milk and milk fat and nutrient digestibility across production level of lactating cows. J. Dairy Sci. 96:7143-7154.

Piantoni, P., A. L. Lock, and M. S. Allen. 2015. Milk production responses to dietary stearic acid vary by production level in dairy cattle. J. Dairy Sci. 98:1938-1949.

Rabiee, A. R., K. Breinhild, W. Scott, H. M. Golder, E. Block, and I. J. Lean. 2012. Effect of fat additions to diets of dairy cattle on milk production and components: A meta-analysis and metaregression. J. Dairy Sci. 95:3225-3247.

Relling, A. E., and C. K. Reynolds. 2007. Feeding rumen-inert fats differing in their degree of saturation decreases intake and increases plasma concentrations of gut peptides in lactating dairy cows. J. Dairy Sci. 90:1506-1515.

Rico, D. E., Y. Ying, and K. J. Harvatine. 2014a. Effect of a highpalmitic acid fat supplement on milk production and apparent total-tract digestibility in high- and low-milk yield dairy cows. J. Dairy Sci. 97:3739-3751.

Rico, J. E., M. S. Allen, and A. L. Lock. 2014b. Compared with stearic acid, palmitic acid increased the yield of milk fat and improved feed efficiency across production level of cows. J. Dairy Sci. 97:1057-1066.

Rico, J. E., J. de Souza, M. S. Allen, and A. L. Lock. 2017. Nutrient digestibility and milk production responses to increasing levels of palmitic acid supplementation vary in cows receiving diets with or without whole cottonseed. J. Anim. Sci. 95:436-446.

Toral, P. G., G. Hervás, D. Carreño, and P. Frutos. 2016. Does supplemental 18:0 alleviate fish oil-induced milk fat depression in dairy ewes? J. Dairy Sci. 99:1133-1144.

Tzompa-Sosa, D. A., G. A. van Aken, A. C. M. van Hooijdonk, and H. J. F. van Valenberg. 2014. Influence of C16:0 and long-chain saturated fatty acids on normal variation of bovine milk fat triacylglycerol structure. J. Dairy Sci. 97:4542-4551.

Urrutia, N., and K. J. Harvatine. 2017. Effect of conjugated linoleic acid and acetate on milk fat synthesis and adipose lipogenesis in lactating dairy cows. J. Dairy Sci. 100:5792-5804.

Vernon, R. G. 2005. Lipid metabolism during lactation: A review of adipose tissue-liver interactions and the development of fatty liver. J. Dairy Res. 72:460-469.

Warntjes, J. L., P. H. Robinson, E. Galo, E. J. DePeters, and D. Howes. 2008. Effects of feeding supplemental palmitic acid (C16:0) on performance and milk fatty acid profile of lactating dairy cows under summer heat. Anim. Feed Sci. Technol. 140:241-258.

Weiss, W. P., J. M. Pinos-Rodríguez, and D. J. Wyatt. 2011. The value of different fat supplements as sources of digestible energy for lactating dairy cows. J. Dairy Sci. 94:931-939.

Weld, K. A., and L. E. Armentano. 2017. The effects of adding fat to diets of lactating dairy cows on total-tract neutral detergent fiber digestibility: A meta-analysis. J. Dairy Sci. 100:1766-1779.

Wildman, E. E., G. M. Jones, P. E. Wagner, R. L. Boman, H. F. Troutt Jr., and T. N. Lesch. 1982. A dairy cow body condition scoring system and its relationship to selected production characteristics. J. Dairy Sci. 65:495-501. 